\title{
Fisheries resources in alleviation of hunger and malnutrition in Sri Lanka - accomplishment and challenges ${ }^{1}$
}

\author{
UPALI S. AMARASINGHE \\ Department of Zoology, University of Kelaniya, Kelaniya GQ11600, Sri Lanka \\ (E-mail: zoousa@kln.ac.lk)
}

\begin{abstract}
Sri Lanka is reputed as a country with better basic health indicators than most countries with comparable per capita incomes, but child under-nutrition in the country is very high. Fisheries sector plays a significant role in alleviating hunger and malnutrition because about $70 \%$ of animal protein of the diets of people comes from this sector. Currently per capita fish consumption in Sri Lanka is $13 \mathrm{~kg}$ per annum. Nevertheless, there is a significant potential to increase this value. Marine fisheries production forms about $86 \%$ of national fish production, but potential for its further increase is remote except for a few under-exploited fish stocks such as those attracted to flotsam. The inland fisheries sub-sector, on the other hand, has a great potential for development through further expansion of culture-based fisheries (CBF) in small village reservoirs for which there are legal provisions for agricultural farmers to utilize them for CBF development. With increased demand for fish fingerlings for CBF, there is an urgent need for training rural farmers to establish mini-hatcheries and induced breeding techniques of major carps. There appears to be a high potential for exploiting small indigenous fish species which have been unexploited hitherto, in reservoirs of Sri Lanka. As such, the fishery regulations with the legal provisions to exploit these indigenous fish populations should be implemented through active participation of fisher communities. The inland fishery is a source of animal protein for rural poor available at affordable prices. Hence, development of this sector is imperative for eradicating hunger and malnutrition in the rural communities.
\end{abstract}

Keywords: culture-based fisheries, flotsam fisheries, food security, reservoir fisheries, small indigenous fish

\section{Introduction}

The member countries of the United Nations have committed to achieve the Millennium Development Goals (MDGs) and accordingly, its target is to halve between 1990 and 2015 the proportion of people living on less than $\$ 1$ a day (a

\footnotetext{
${ }^{1}$ Paper presented at the Global Symposium on Aquatic Resources for Eradicating Hunger and Malnutrition - Opportunities and Challenges that was held from $4^{\text {th }}$ to $6^{\text {th }}$ December 2012, Mangalore, Karnataka, India.
} 
measure of income poverty) and the proportion of people suffering from hunger (a measure of the non-income face of poverty). Sri Lanka is reputed as a country with better basic health indicators than most countries with comparable per capita incomes. However, child under-nutrition in Sri Lanka is very high (Anon. 2010). Malnutrition and income poverty are known to be highly correlated and income is one of the major determinants influencing children's nutrition (Strauss and Thomas 1995).

In Sri Lanka, the contribution of the fisheries sector to the Gross Domestic Product (GDP) has been marginal (1.2\%) (Anon. 2011). Nevertheless, the sector contributes around $70 \%$ of the animal protein of the diet of people (Anon. 2007). In this paper, the role of fisheries and aquaculture of Sri Lanka in alleviating hunger and malnutrition is reviewed.

\section{Fisheries sector: Current Status}

In Sri Lanka, marine fishery dominates the total fish production with a percentage contribution of $86 \%$. Inland fisheries and aquaculture form $14 \%$ of the total fish production (Figure 1). Currently per capita fish consumption in Sri Lanka is $13 \mathrm{~kg}$ per annum (http://www.fisheries.gov.lk/statistics.html), which is much lower than the global annual average of $18.8 \mathrm{~kg}$ (FAO 2012). The fisheries sector of Sri Lanka provides direct employment to about 150,000 people while another 100,000 are employed in related activities. Also, about 400,000 people are employed in fish trade and allied activities. 


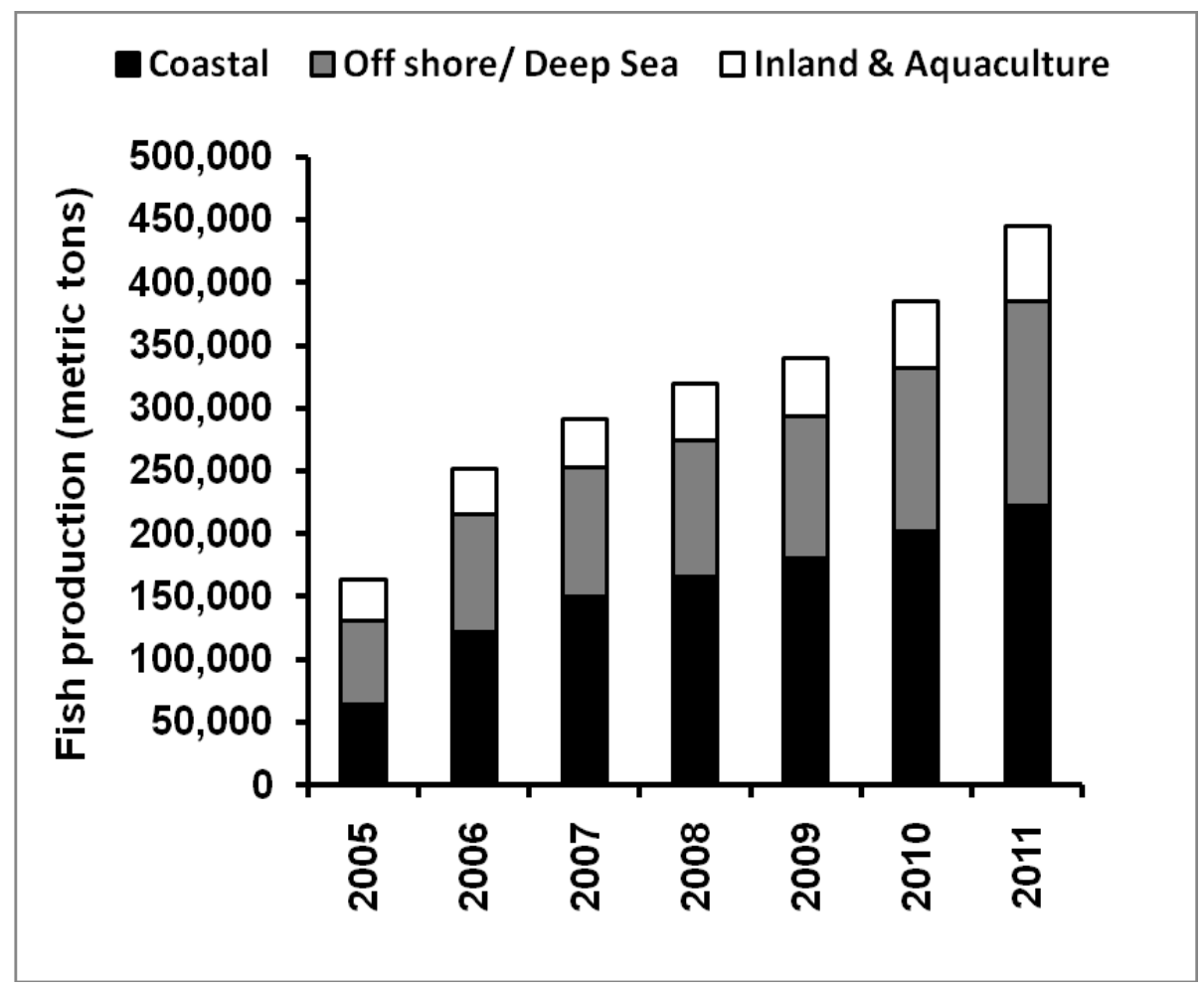

Figure 1. Fish production from different sub-sectors in Sri Lanka.

Source: http://www.fisheries.gov.lk/statistics.html

\section{Marine fisheries}

The extent of Exclusive Economic Zone (EEZ) of Sri Lanka is about $517,000 \mathrm{~km}^{2}$ and about $5.7 \%$ of which is covered by the continental shelf with the average width of 22 $\mathrm{km}$. The coastal fisheries sub-sector in this continental shelf area produces about $50 \%$ of total annual fish production. In the offshore and deep sea fisheries sub-sector, multiday boats are operated and the major fishing gear types are drift gillnetting and long lining. There has been a recent trend that crew members of some multi-day boats (especially in the southern Sri Lanka) operate surrounding nets to catch fishes attracted to flotsam and the major species caught are Decapterus russelli, Elagatis bipinnulata, Coryphaena hippurus and Abalistes stellatus (Ariyaratne and Amarasinghe 2012). This study also indicated that juvenile tunas (15-60 cm TL) were caught in flotsamassociated surrounding nets as they aggregated around floating objects in offshore areas. As floating objects are known to aggregate pelagic fish, they may affect migratory behaviour of fish and their overall biology may be affected due to maladaptation to the artificial habitat, which is speculated by the ecological trap hypothesis (Dagorn et al. 2010). The analysis of the changes of behavioural patterns due to attraction to flotsam and biological consequences of life-history changes such as growth and body condition of fish are therefore needed to be investigated. 


\section{Inland Fisheries}

The commercial-scale inland capture fisheries come from major irrigation and hydroelectric reservoirs ( $>750 \mathrm{ha}$ ) and the total extent of such reservoirs is about 70,000 ha (about $42 \%$ of the total extent of lentic water bodies). Small-scale fisheries exist in the medium-scale reservoirs (250-750 ha), which form about $10 \%$ of the total extent. The minor irrigation reservoirs $(<250 \mathrm{ha})$, generally referred to as "village tanks" the cumulative extent of which is about 39,000 ha, can be categorized into two groups depending on the water retention period. The reservoirs which retain water throughout the year are called "minor perennial reservoirs" and those which retain water for 7-9 months each year are locally known as "seasonal reservoirs" or "nonperennial reservoirs" (Mendis 1977). In the minor perennial reservoirs, subsistence level fisheries exist (Murray et al. 2001; Pushpalatha and Chandrasoma 2010). The non-perennial reservoirs are small $(<60$ ha) and are largely rain-fed (from intermonsoonal and northeast monsoonal rains from October to January). They tend to be eutrophic due to addition of nutrients from the catchment areas. The inland fish production is essentially from the multitude of reservoirs of the country. The positive relationship between reservoir extent in each district and district-wise inland fish production (Figure 2) indicates the importance of the reservoir resource for inland fish production.

\section{Culture-based fisheries}

The inland fisheries sub-sector includes capture fisheries in inland waters, culturebased fisheries and shrimp farming (Table 1). It must be noted however, that the CBF production in minor perennial reservoirs of the country is included under the category of inland capture fisheries. Total annual $\mathrm{CBF}$ production from minor perennial reservoirs as a percentage of total inland capture fisheries production is about $2.25 \%$ (Table 2).

Hatchery reared fish are released into seasonal reservoirs and minor perennial reservoirs not primarily managed for fish production, and are recaptured upon reaching a desirable size (De Silva 2003). This enhancement strategy termed as culture-based fisheries (CBF) was suggested to be managed by the rural communities, whose livelihoods were dependent on reservoirs for irrigation of agricultural lands, watering their cattle and buffaloes and domestic uses (Mendis 1977). CBF combine elements of aquaculture and capture fisheries and rely entirely on the natural productivity of the water body for growth of fish, and on artificial stocking as a means of recruitment (Lorenzen 1995). 
Table 1. Inland fisheries and aquaculture production (metric tons) in Sri Lanka - 2011 (http://www.fisheries.gov.lk/statistics.html)

\begin{tabular}{ll}
\hline & Production/year \\
\hline Capture fisheries & 50,050 \\
Culture-based fisheries in non-perennial reservoirs & 5,360 \\
Shrimp farming & 4,150 \\
Total & 59,560 \\
\hline
\end{tabular}

Table 2. Annual CBF production of minor perennial reservoirs as deduced from the available information (adopted from Amarasinghe 2010).

\begin{tabular}{lll}
\hline & 2007 & 2008 \\
\hline $\begin{array}{l}\text { Number of fingerlings stocked in minor perennial } \\
\text { reservoirs }\left(\mathrm{x} 10^{6}\right)^{1}\end{array}$ & 4.61 & 5.70 \\
$\begin{array}{l}\text { Estimated total extent of minor perennial } \\
\text { reservoirs stocked (ha) }{ }^{2}\end{array}$ & 6,147 & 7,600 \\
$\begin{array}{l}\text { Estimated CBF production from minor perennial } \\
\text { reservoirs (tonnes) }\end{array}$ & 1,279 & 1,581 \\
Total inland capture fisheries production (tonnes) & \\
CBF production from minor perennial reservoirs & 30,200 & 37,170 \\
as a percentage of total inland capture fisheries \\
production
\end{tabular}




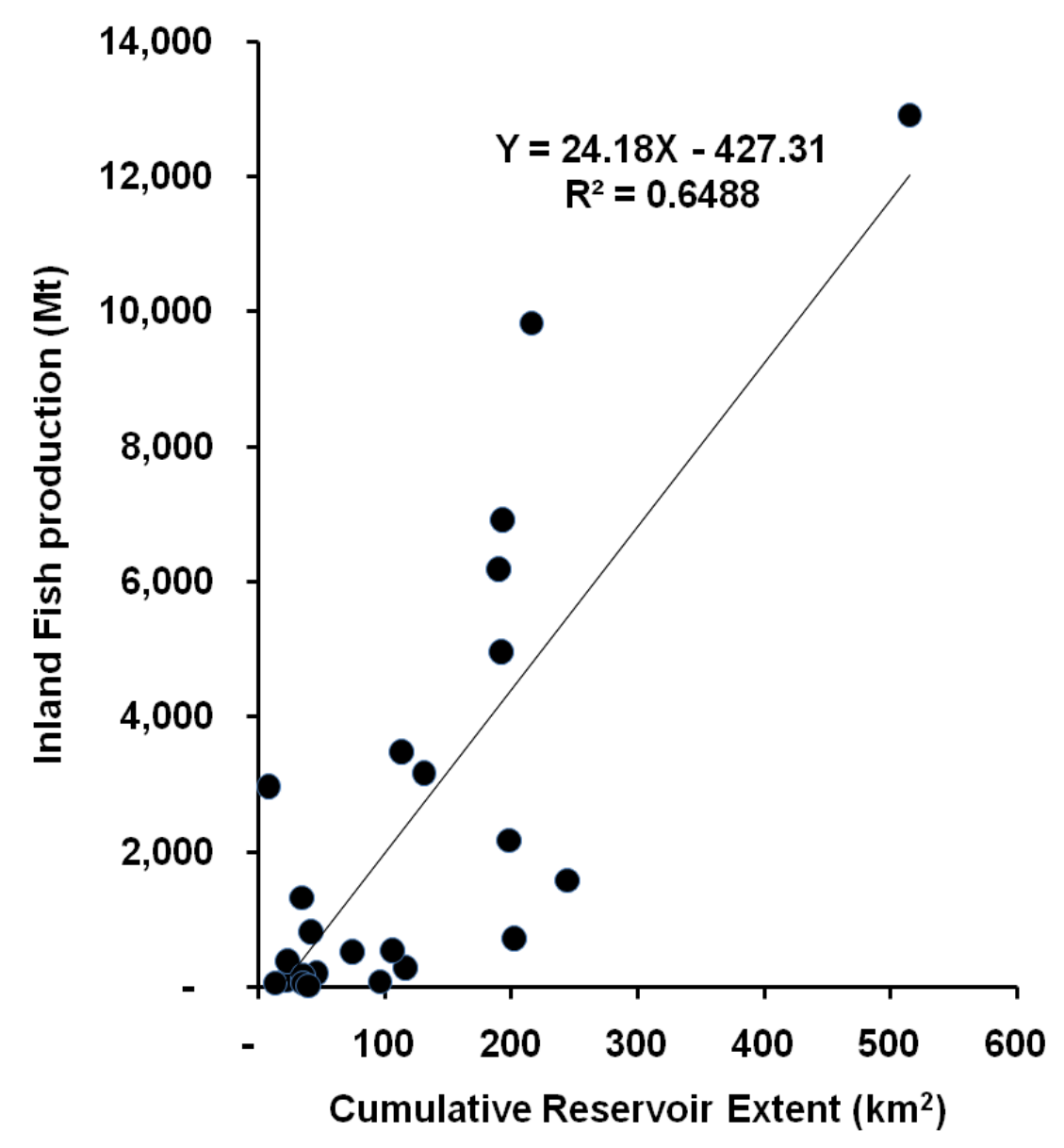

Figure 2. The relationship between reservoir extent in each district and district-wise inland fish production (Sources of data: www.naqda.gov.lk; www.fisheries.gov.lk)

The CBF development is essentially a fisheries enhancement strategy. For the CBF development strategies in non-perennial (seasonal) reservoirs and minor perennial reservoirs $(<250 \mathrm{ha})$, two different types of fisheries enhancement activities are practiced. The features of enhancement strategies and regulatory measures in the two types of reservoirs are given in Table 3 . The inland fish production in terms of capture fisheries in major and medium-sized irrigation and hydroelectric reservoirs, and CBF production in minor perennial reservoirs and seasonal reservoirs during 2007-2008 are shown in Figure 3. 
Table 3. The features of enhancement strategies and regulatory measures in the two types of reservoirs in Sri Lanka (adopted from Amarasinghe 2010).

\begin{tabular}{|c|c|c|}
\hline & Non-perennial reservoirs & Minor perennial reservoirs \\
\hline $\begin{array}{l}\text { Ownership and jurisdiction } \\
\text { of water uses }\end{array}$ & $\begin{array}{l}\text { Agrarian Development } \\
\text { Department; Farmer } \\
\text { organizations }\end{array}$ & $\begin{array}{l}\text { Irrigation Department or } \\
\text { Agrarian Development } \\
\text { Department; Farmer } \\
\text { organizations }\end{array}$ \\
\hline $\begin{array}{l}\text { Responsible community } \\
\text { group for } \mathrm{CBF}\end{array}$ & $\begin{array}{l}\text { Agricultural farmers } \\
\text { (traditionally non- } \\
\text { fishers) }\end{array}$ & $\begin{array}{l}\text { Agricultural farmers } \\
\text { (traditionally non-fishers) } \\
\text { and/or fishers }\end{array}$ \\
\hline $\begin{array}{l}\text { Stocking density (nos ha }{ }^{-1} \text {, } \\
\left.\mathrm{yr}^{-1}\right) \\
\text { Stocking size }(\mathrm{cm})\end{array}$ & $2000-2500$ & $217-870$ \\
\hline Major carps & $5-6$ & $5-6$ \\
\hline Nile tilapia & $6-8$ & $6-8$ \\
\hline Stocking frequency & $\begin{array}{l}\text { After peak rainy season } \\
\text { in November-January }\end{array}$ & $\begin{array}{l}\text { Once a year when } \\
\text { fingerlings are not needed } \\
\text { for stocking seasonal } \\
\text { reservoirs }\end{array}$ \\
\hline Harvesting & $\begin{array}{l}\text { During dry season; } \\
\text { complete harvesting }\end{array}$ & $\begin{array}{l}\text { Year-round harvesting of } \\
\text { surplus biomass }\end{array}$ \\
\hline Harvesting methods & $\begin{array}{l}\text { Seining; gillnetting, cast } \\
\text { netting }\end{array}$ & $\begin{array}{l}\text { Gillnetting }(8.5-20 \mathrm{~cm} \\
\text { mesh) }\end{array}$ \\
\hline Management & $\begin{array}{l}\text { Farmer organizations } \\
\text { (FOs) }\end{array}$ & $\begin{array}{l}\text { Farmer organization/ } \\
\text { fishers }\end{array}$ \\
\hline Funding for $\mathrm{CBF}$ & $\begin{array}{l}\text { Revolving fund raised } \\
\text { by the FO }\end{array}$ & $\begin{array}{l}\text { Revolving fund raised by } \\
\text { the FO/ fisheries society }\end{array}$ \\
\hline
\end{tabular}

Sources of information: De Silva et al. (2006); Pushpalatha and Chandrasoma (2010). 


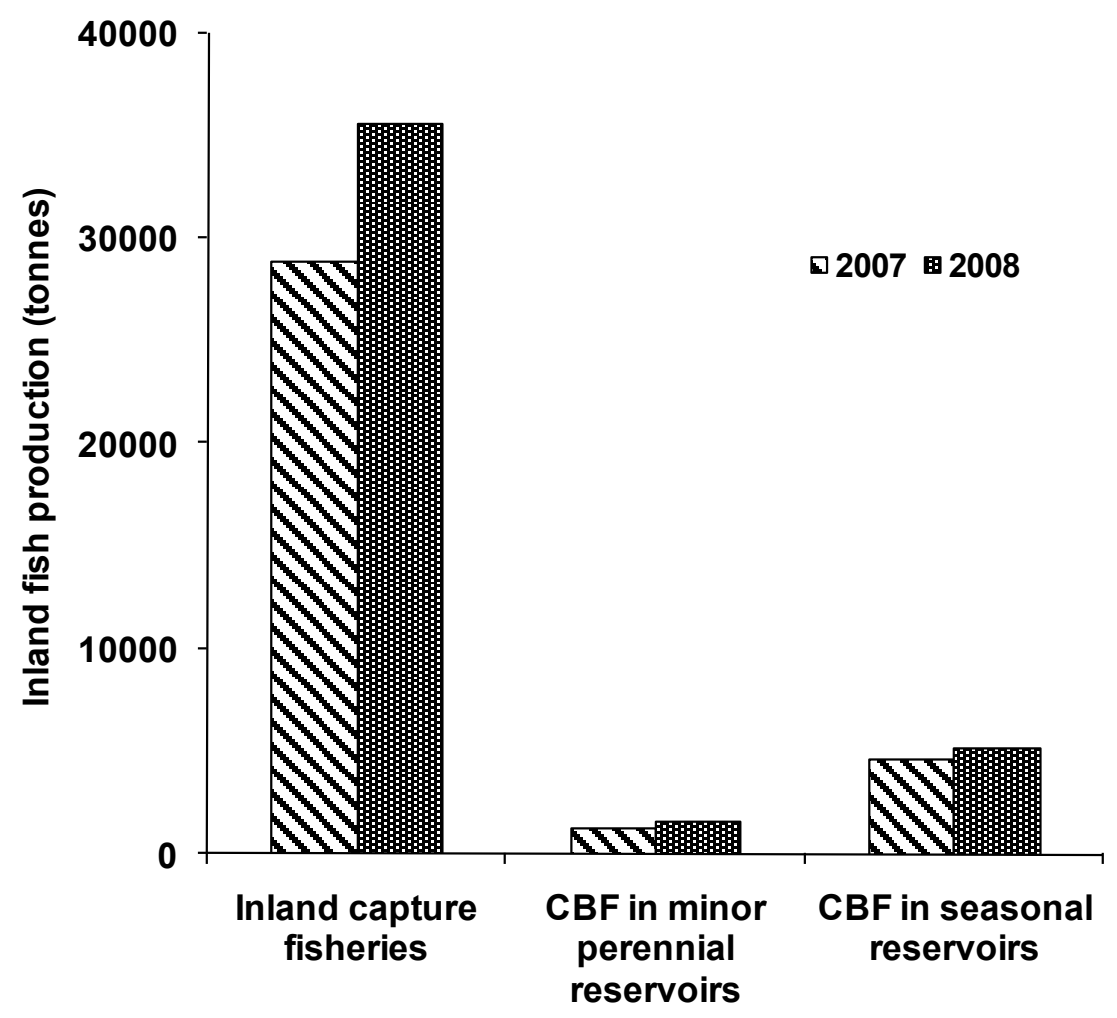

Figure 3. The annual inland fisheries production from capture fisheries and culturebased fisheries during 2007-2008 (adopted from Amarasinghe 2010).

In the 1980s, CBF development in village reservoirs was incorporated in the national fisheries development plan of the country. However, this strategy was highly subsidized by the government, providing fish fingerlings free-of-charge for stocking and adopting a top-down approach for introducing CBF to rural agricultural communities. The CBF development programme in village reservoirs did not sustain in 1980s and according to De Silva (2003), the likely reasons for the overall failure of the strategy were,

- the lack of a guaranteed fingerling supply, resulting in under-stocking of reservoirs and in turn, not making use of the growing season fully;

- the oversupply of produce in space and time;

- rules and regulations pertinent to $\mathrm{CBF}$ development in village reservoir were not in place; and

- the supply of undersized and poor conditioned fingerlings resulting in low returns.

Also, a politically inspired decision to withdraw state patronage for the development of the inland fisheries and aquaculture sector from 1990 to 1994 was a major setback to the development of CBF (de Silva 1991; Amarasinghe 1998). The 
government hatcheries, which were leased out to private sector after cessation of government support in 1990 brought about general collapse of CBF development activities in village reservoirs due to the lack of fingerling supply for CBF. After the government-owned fish breeding centres were leased out to the private sector in 1990, none of the private organizations continued induced breeding of exotic carps for CBF and pond culture but used pond space in the fish breeding centres to rear more lucrative ornamental fish species for export market.

The state patronage for inland fisheries and aquaculture development was revived in 1994, and thereafter, instead of the usual practice of fingerling production in government hatcheries, fingerling production for stocking inland water bodies through community participation was recognized as a feasible strategy, as suggested by Amarasinghe $(1992,1995)$. Induced breeding and rearing of post-larvae up to fry stage (2-3 cm in size) were carried out at government hatcheries. Also, extension mechanism in the inland fisheries and aquaculture sub-sector has been strengthened after the establishment of National Aquaculture Development Authority of Sri Lanka (NAQDA) under a Parliamentary Act in 1998 (Anon. 1998; Anon. 2006a).

\section{Fish species cultured}

Due to the absence of fast-growing fish species in Sri Lankan indigenous fish fauna, which feed on lower trophic levels, exotic species are used for inland fisheries enhancement strategies. Hatchery-produced fingerlings of catla (Catla catla), rohu (Labeo rohita), mrigal (Cirrhinus mrigala), bighead carp (Aristichthys nobilis), common carp (Cyprinus carpio) silver carp (Hypophthalmichthys molitrix), grass carp (Ctenopharyngodon idella) are generally stocked in seasonal reservoirs and minor perennial reservoirs. In addition, Nile tilapia (Oreochromis niloticus) GIFT (genetically improved farmed tilapia) strain of $O$. niloticus and freshwater prawn (Macrobrachium rosenbergii) are stocked by some community-based organizations (CBOs). However, GIFT strain on Nile tilapia is not suitable for fisheries enhancement through CBF in village reservoirs of Sri Lanka because they showed poor growth performance perhaps due to their inability to compete with other stocked species for natural food (Wijenayake et al. 2007).

Information about stocking in minor perennial reservoirs and seasonal reservoirs is available for the 2007-2008 period (Pushpalatha and Chandrasoma 2010; Amarasinghe 2010). Stocking densities in minor perennial reservoirs ranged from 500 to 1000 fingerlings per ha. In 2007, 213 minor perennial reservoirs were stocked with 4.61 million fingerlings. In 2008, 5.70 million fingerlings were stocked in 218 minor perennial reservoirs (www.fisheries.gov.lk). Due to shortage of fingerlings, stocking density used in seasonal reservoirs was 1000-1500 fingerlings per ha. Accordingly in 2007, 4.06 million fingerlings were stocked in 472 seasonal reservoirs and in 2008, 321 seasonal reservoirs were stocked with 3 million fingerlings. CBF development in seasonal reservoirs is essentially dependent on the rainfall pattern in the dry zone of the country. As the fingerlings should be stocked in seasonal reservoirs just after the heaviest rainy season (November-January) in the dry zone of the country during when the reservoirs get filled, correct timing of production of fingerlings is necessary for successful implementation of culture based fisheries in seasonal reservoirs. Also, 
fingerlings are not required for stocking in seasonal reservoirs during all the seasons, so that they can be stocked into small perennial reservoirs (Table 3).

The above evidence suggests that the present scale of operation of CBF in Sri Lanka remains at a very low level, with only about $4.7 \%$ of existing small reservoirs (about 470 reservoirs out of about 10,000 village reservoirs) are stocked annually. Apparently, a major set-back for further development of CBF strategy in the country is scarcity of fingerlings. For the CBF development, fingerlings of Chinese and Indian major carps are supplied by three Aquaculture Development Centres (AQDCs) functioning under NAQDA. As the technology of induced breeding has not yet been adopted by rural farmers or private sector, AQDCs are responsible for induced breeding and rearing of post-larvae to fry stage. Due to the limited pond space, the AQDCs are incapable of rearing of fish fry to fingerling size to meet the present demand. Private pond owners and CBOs are also responsible for fingerling rearing in addition to AQDCs. The mini-nurseries established by CBOs purchase fish fry from AQDCs at the rate of SLRs. 0.25 per fry (In October 2012, US\$ $1=$ SLRs 128.4). Selling fish fry and fingerlings to stakeholders has been a recent development following a policy decision taken by NAQDA after its establishment in 1998 (Weerakoon 2007). The fingerlings are sold at the unit price of SLRs. 2.00 per fingerling.

An increase of the country's inland fisheries and aquaculture production from the figure of $36,530 \mathrm{mt}$ in 2006 to $74,450 \mathrm{mt}$ in 2016 has been envisaged, under the "Ten Year Development Policy Framework of the Fisheries and Aquatic Resources Sector 2007-2016" (Anon. 2007). To achieve this target of 104\% increase of inland fisheries production in the country, the following strategies have been identified.

- Increase fish production in minor perennial reservoirs and seasonal tanks through culture based fisheries;

- Increase Indian carp production through stock enhancement programmes in major and medium perennial reservoirs;

- Increase supply of fish seed for stock enhancement by rehabilitating Government centres and construction of mini nurseries to be operated by Community-based Organizations (CBOs);

- Strictly implement community based fisheries management in perennial reservoirs;

- Promote the efficient collection of catch statistics from perennial reservoirs;

- Promote commercial aquaculture through public/private sector participatory demonstration projects in collaboration with SME banks;

- Promote carp culture in estate tanks; and

- Undertake aquaculture research \& development in collaboration with research agencies.

The main technology of producing seeds of major carps in the hatcheries of AQDCs is induced breeding with the use of Ovoprim, Sufrefact, Human Chorionic Gonadotropin (HCG), Luteinizing Hormone Release Hormone Analog (LHRH Analog) and Pituitary Glands (PG) (Weerakoon 2007). With increased demand for fish 
fingerlings for fisheries enhancement, there is an urgent need for training rural farmers to establish mini-hatcheries and induced breeding techniques of major carps.

As CBF falls within the realm of aquaculture (De Silva 2003), it is necessary to define ownership of the CBF system for sustainability. Under the section 39 of the Fisheries and Aquatic Resources Act No. 2 of 1996 (Anon. 1996a) and amended act No. 22 of 2006 (Anon. 2006b), there are legal provisions for licensing aquaculture enterprises, under which aquaculture management regulations were implemented in 1996 (Anon. 1996b). Kularatne et al. (2009) found that there were socioeconomic characteristics favouring collective decision making for $\mathrm{CBF}$ development such as good leadership of officers in the society, high percentages of active members with common interest and high degree of participation in collective work, small group size and high percentage of kinship in the group.

Fisheries enhancement in seasonal reservoirs through CBF is a secondary use of small-sized village reservoirs, which have not been traditionally used for fish production (Amarasinghe and Nguyen 2009). CBF in village reservoirs is practised by agrarian communities rather than fishers. As the village reservoirs (with command area of less than $80 \mathrm{ha}$ ) come under the jurisdiction of Department of Agrarian Development, legal provisions in the Agrarian Development Act No. 46 of 2000 for incorporating fisheries and aquaculture aspects in reservoir management, facilitate fisheries enhancement. The Department of Agrarian Development plays facilitative role while enacting certain regulations for agricultural development. The existing management regimes in the village reservoirs therefore are driven by the strong commitment of the government to institutionalize the position of agrarian communities.

Amarasinghe and Nguyen (2009) reported financial benefits of CBF in 23 seasonal reservoirs. The farm-gate price per $\mathrm{kg}$ of fish ranged from Rs. 30 to Rs. 75 . From every harvest, villagers took fish for home consumption. Especially in reservoirs with rich harvests, aquaculture committees gave villagers fish free-of-charge. However, this portion of the harvest was significant and ranged from 3 to $47 \%$. Considering the value of the 'home-consumption' portion of the harvest (i.e., subsistence harvest), as determined on the basis of farm-gate value of fish, the net profit ranged from SLRs. 47,372 to SLRs. 729,339 (In October 2012, US\$ 1 = SLRs 128.4).

The entire inland fish production of the country is not exported but consumed locally and as such, inland fishery of Sri Lanka is an extremely important sector for meeting nutritional demand of people. The inland fish prices are much lower than those of most marine fish varieties (Figure 4) and as such, inland fishery is a source of animal protein for the rural poor available at affordable prices.

\section{Unexploited fishery resources in inland waters}

In 1980s and 1990s several studies (De Silva and Sirisena 1987, 1989; Amarasinghe 1990; Pet and Piet 1993) have demonstrated that small-sized indigenous cyprinid stocks in perennial reservoirs could be exploited using small meshed gillnets and that such a fishery will not directly and/or indirectly impact on the existing fishery for exotic cichlids. The main indigenous cyprinid species caught in small meshed gillnets, in order of abundance were Amblypharyngodon melettinus, Puntius chola, $P$. filamentosus, P. dorsalis, Rasbora daniconius amongst others. In many reservoirs of 
the country, fishers have also been exploiting this resource for nearly 6 to 8 years using $20-25 \mathrm{~mm}$ mesh gillnets with 8 to 20 net panels of approximately $25 \mathrm{~m} \times 3.5 \mathrm{~m}$ dimensions.

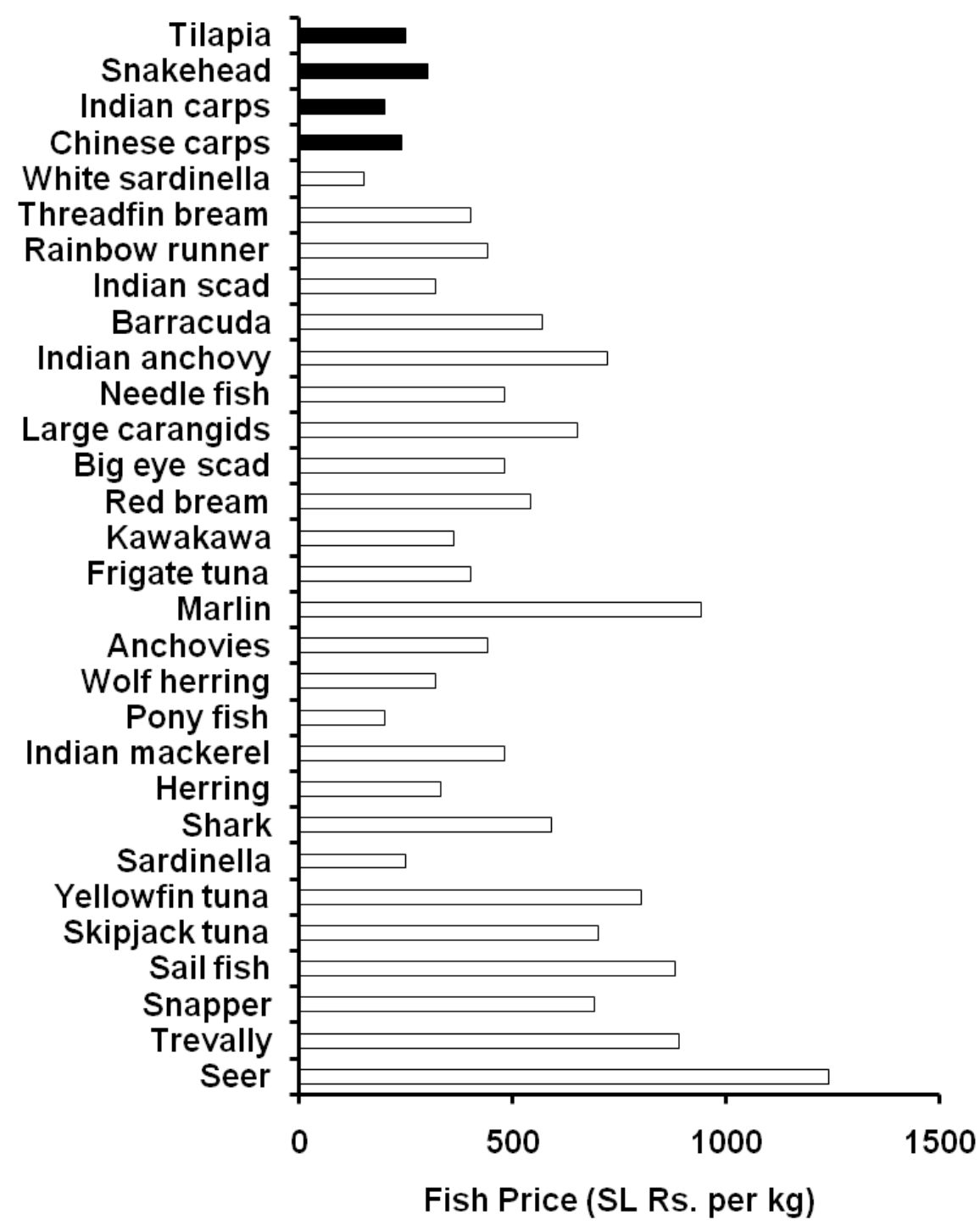

Figure 4. Average marine (white bars) and freshwater (black bars) fish prices at selected fish narkets in 2012.

These fishers, numbering 10 to 20 in each of the reservoirs caught on average 15 to $200 \mathrm{~kg}$ of small indigenous cyprinids per day (mean $46 \mathrm{~kg}$ per fisher per day), and on the most productive days the catch could exceed $200 \mathrm{~kg}$ per fisher. Research on postharvest technology for this untapped fishery resource is also needed to improve consumer acceptance (Amarasinghe et al. 2009). Small indigenous cyprinids can also 
be used to prepare feeds in aquaculture systems and livestock industry (Amarasinghe et al. 2002). Evidence is found in other south Asian countries such as Bangladesh that small indigenous fish species have significantly high potential for contributing to human nutrition, especially due to the reason that some species such as Amblypharyngodon mola are found to be rich in vitamin A (Roos et al. 2007). These small indigenous fish species are sold as dried fish in many reservoirs of the country. Due to the apparent high potential for exploiting these untapped fishery resources, the fishery regulations with the legal provisions to exploit fish populations, which have been unexploited hitherto, should be implemented through active participation of fisher communities.

\section{Conclusion}

Although marine fisheries production forms about $86 \%$ of national fish production, potential for its further increase is remote except for a few under-exploited fish stocks such as those attracted to flotsam. The inland fisheries sector on the other hand, continues to make a significant impact on the rural economy due to its vast potential for development. Small village reservoirs, which have not been traditionally used for fish production, can be utilized for the development of culture-based fisheries (CBF) as they are known to be biologically productive. Legal provisions are available for implementing $\mathrm{CBF}$ in village reservoirs, which come under the jurisdiction of the Department of Agrarian Development, and as such, CBF is an effective means for rural development in the country. Furthermore, inland fisheries production provides a source of animal protein for rural communities at affordable prices. The small-sized indigenous cyprinid species in major reservoirs of Sri Lanka remain unexploited and they can be differentially harvested using small mesh $(20-25 \mathrm{~mm})$ gillnets without any direct and/or indirect impact on the existing fishery for exotic cichlids. Due to the apparent high potential for exploiting these untapped fishery resources, and rich nutritive quality of small indigenous species, the fishery regulations with the legal provisions to exploit fish populations, which have been unexploited hitherto, should be implemented through active participation of fisher communities.

\section{References}

Amarasinghe, U.S. 1990. Minor cyprinid resources in a man-made lake in Sri Lanka: a potential supplementary source of income for fishermen. Fisheries Research 9: 81-89.

Amarasinghe, U.S. 1992. Recent trends in the inland fishery of Sri Lanka. pp. 84-105. In: E.A. Baluyut ed. FAO Fisheries Report No. 458, Suppl. FAO, Rome.

Amarasinghe, U.S. 1995. Sustainable development of the inland fishery of Sri Lanka under environmental constraints. pp. 160-176. In: T. Petr \& M. Morris, eds. FAO Fisheries Report No. 512, Suppl. FAO, Rome.

Amarasinghe, U.S. 1998. Reservoir fisheries management in Sri Lanka: Achievements, mistakes and lessons for future. International Review of Hydrobiology 83 (Special Issue): 523-530. 
Amarasinghe, U.S. 2010. Inland fisheries resource enhancement and conservation in Sri Lanka. pp. 113-132. In: Miao Weimin, Sena De Silva and Brian Davy (eds) Inland Fisheries Resource Enhancement and Conservation in Asia. FAO RAP Publication 2010/22, FAO Regional Office for Asia and the Pacific, Bangkok.

Amarasinghe, U.S. and T.T.T. Nguyen 2009. Enhancing rural farmer income through fish production: Secondary use of water resources in Sri Lanka and elsewhere. pp. 103-130. In: S.S. De Silva and F.B. Davy (eds) Success Stories in Asian Aquaculture. Dordrecht, Springer Science.

Amarasinghe, U.S., P.A.D. Ajith Kumara, and M.H.S. Ariyaratne 2002. Role of nonexploited fishery resources in Sri Lankan reservoirs as a source of food for cage aquaculture. pp. 332-343. In: I.G. Cowx (ed.) Management and Ecology of Lake and Reservoir Fisheries. Fishing News Books, Blackwell Science, Oxford.

Amarasinghe, U.S., D.E.M. Weerakoon and D.A. Athukorala 2009. Emerging boost in Sri Lankan reservoir fish production: a case of adoption of past research findings. Aquaculture Asia 14 (1): 26-28.

Ariyaratne, M.M. and U.S. Amarasinghe 2012. A fishery associated with floating objects in the Indian Ocean off Southern Sri Lanka. Asian Fisheries Science 25: 278-289.

Anon. 1996a. Fisheries and Aquatic Resources Act No. 2 of 1996. Colombo, Sri Lanka, The Gazette of Sri Lanka of 11 January 1996.

Anon. 1996b. Aquaculture Management Regulations of 1996. Colombo, Sri Lanka, The Gazette of Sri Lanka (Extraordinary) of 7 November, 1996.

Anon. 1998. The National Aquaculture Development Authority of Sri Lanka Act, No. 53 of 1998, Colombo, Sri Lanka.

Anon. 2006a. National Aquaculture Development Authority of Sri Lanka (Amendment) Act, No. 23 of 2006. 16 August 2006. Colombo, Sri Lanka, Parliament of Sri Lanka.

Anon. 2006b. Fisheries and Aquatic Resources (Amendment) Act No. 22 of 2006. 16 August 2006. Parliament of Sri Lanka, Colombo, Sri Lanka.

Anon. 2007. Ten Year Development Policy Framework of the Fisheries and Aquatic Resources Sector, 2007-2016. Ministry of Fisheries and Aquatic Resources, Colombo. 24 p.

Anon. 2010. Millennium Development Goals Sri Lanka: Country Report 2008/2009. Institute of Policy Studies of Sri Lanka, Colombo. 168p.

Anon. 2011. National Output and Expenditure, Annual Report - 2011. Pp. 31-58. Central Bank of Sri Lanka, Colombo.

Dagorn, L., K.N. Holland and J. Filmalter 2010. Are drifting FADs essential for testing the ecological trap hypothesis? Fisheries Research 106: 60-63.

de Silva, K.H.G.M. 1991. The predicament of the freshwater fisheries and aquaculture of Sri Lanka. NAGA, the ICLARM Quarterly 14: 6-7.

De Silva, S.S. 2003. Culture-based fisheries: an underutilized opportunity in aquaculture development. Aquaculture 221: 221-243.

De Silva, S.S. and H.K.G. Sirisena 1987. New fish resources of reservoirs in Sri Lanka. Feasibility of introduction of a subsidiary gillnet fishery for minor cyprinids. Fisheries Research 6: 17-34. 
De Silva, S.S. and H.K.G. Sirisena 1989. New fish resources of reservoirs in Sri Lanka. 3. Results of commercial-scale trials and yield estimates of a gillnet fishery for minor cyprinids. Fisheries Research 7: 279-287.

De Silva, S.S., U.S. Amarasinghe and T.T.T. Nguyen 2006. Better-practice approaches for culture-based fisheries development in Asia. ACIAR Monograph No. 120, Australian Centre for International Agricultural Research, Canberra and Network of Aquaculture Centres in Asia-Pacific, Bangkok. 96 p.

FAO 2012. World review of fisheries and aquaculture, Part 1. Food and Agriculture Organization of the United Nations, Rome.

Kularatne, M.G., U.S. Amarasinghe, P. Wattage and S.S. De Silva 2009. Evaluation of community participation for the development of culture-based fisheries in village reservoirs of Sri Lanka. Aquaculture Economics and Management 13: 22-38.

Lorenzen, K. 1995. Population dynamics and management of culture based fisheries. Fisheries Management and Ecology 2: 61-73.

Mendis, A.S. 1977. The role of man made lakes in the advancement of fisheries in Sri Lanka. Proceedings of the Indo-Pacific Fisheries Commission 17(3): 247-254

Murray, F.J., S. Kodituwakku and D.C. Little 2001. Fisheries marketing system in Sri Lanka and their relevance to local reservoir fishery development. pp. 56-65. In: S.S. De Silva (ed.) Reservoir and Culture-based Fisheries: Biology and Management. ACIAR Proceedings No. 98, Australian Centre for International Agricultural Research, Canberra.

Pet, J.S. and G.J. Piet 1993. The consequences of habitat occupation and habitat overlap of the introduced tilapia Oreochromis mossambicus and indigenous fish species for fishery management in a Sri Lankan reservoir. Journal of Fish Biology 43 (Supplement A): 193-208.

Pushpalatha, K.B.C. and J. Chandrasoma 2010. Culture-based fisheries in minor perennial reservoirs in Sri Lanka: variability in production, stocked species and yield implications. Journal of Applied Ichthyology 26: 99-104.

Roos, N., A. Md. Wahab, M.A.R. Hossain and S.H. Thilsted 2007. Linking human nutrition and fisheries: Incorporating micronutrient-dense, small indigenous fish species in carp polyculture production in Bangladesh. Food and Nutrition Bulletin 28(2) (supplement): S280-S293.

Strauss, J. and D. Thomas 1995. Human resources: empirical modeling of household and family decisions. pp. 1883-2023. In: J. Behrman and T.N. Srinivasan (eds.), Handbook of development economics. Elsevier Science, Amsterdam.

Weerakoon, D.E.M. 2007. Freshwater fish seed resources in Sri Lanka. pp. 425-440. In: M.G. Bondad-Reantaso (ed.) Assessment of freshwater fish seed resources for sustainable aquaculture. FAO Fisheries Technical Paper No. 501, 628 p. Rome.

Wijenayake, W.M.H.K., U.S. Amarasinghe and S.S. De Silva 2007. Performance of GIFT strain of Oreochromis niloticus in culture-based fisheries in nonperennial reservoirs, Sri Lanka. Sri Lanka Journal of Aquatic Sciences 12: 118. 